\title{
CARBOXYPEPTIDASE Y CATALYZED C-TERMINAL MODIFICATIONS OF PEPTIDES
}

\author{
by \\ KLAUS BREDDAM, FRED WIDMER and JACK T. JOHANSEN \\ Department of Chemistry, Carlsberg Laboratory \\ Gamle Carlsberg Vej 10, DK-2500 Copenhagen Valby
}

Keywords: Enzymatic synthesis, peptide synthesis, carboxypeptidase $\mathrm{Y}$, transpeptidation

It is demonstrated that carboxypeptidase $Y$ catalyzes the exchange of C-terminal amino acid residues in peptides for various other groups. Using $\mathrm{N}$-blocked dipeptides as substrates and alcohols, ammonia, glycine, glycine amide and glycine methyl ester as nucleophiles, it is shown that peptides can be converted to peptide esters, peptide amides and to peptides with altered C-terminal amino acid residues. The incorporation of the different amine nucleophiles could be studied in a wide $\mathrm{pH}$ range, since the products were resistant towards further degradation. However, the conversion of peptides to peptide esters by alcoholysis was limited to $\mathrm{pH}$ below 4, due to enzymatic hydrolysis of the reaction product. The $\mathrm{pH}$ profile for the incorporation of the various amine nucleophiles suggests that they bind at the same location as the $\mathrm{C}$-terminal amino acid residue of the peptides. The binding of glycine amide and glycine methyl ester to the enzyme, prior to aminolysis, is dependent on the state of ionization of a residue with a $\mathrm{pK}_{\mathrm{a}}$ of $6.6-7.1$.

It is further demonstrated that the coupling yields for all the transacylation reactions, catalyzed by carboxypeptidase $y$, are dependent on the hydrophobicity of the amino acid leaving the active site. A pronounced influence of the penultimate residue of the substrate is demonstrated as well. The implications are discussed.

\section{INTRODUCTION}

The ability of proteolytic enzymes to catalyze the formation of peptide bonds, i.e., the reversal of their normal catalytic action, has recently been the subject of much interest (reviewed by $\mathbf{J}$.

FRUTON (6)). We have demonstrated that carboxypeptidase $Y(C P D-Y)^{1}$ from yeast could become an important tool in peptide synthesis, since this enzyme, in comparison with previously describ-

Abbreviations: $\mathrm{Bz}=$ benzoyl, $\mathrm{CBZ}=$ carbobenzoxy, $\mathrm{CPD}-\mathrm{Y}=$ carboxypeptidase $\mathrm{Y}, \mathrm{HPLC}=$ high pressure liquid cromatography, TEAF = triethyl ammonium formate. All other abbreviations of amino acids, amino acid derivatives and peptides are according to the guideline of the IUPAC-IUB Commission on Biochemical Nomenclature. 
ed enzymes, is better suited for step-wise peptide synthesis $(3,4,18,19,20,21)$.

The CPD-Y catalyzed hydrolysis of peptide esters proceeds via an acyl-enzyme intermediate (1), and in the presence of various amine nucleophiles (amino acids and amino acid derivatives) a partitioning between hydrolysis and aminolysis takes place with the formation of a new peptide bond as a consequence. Since all the hydrolytic reactions catalyzed by CPD.Y proceed via an acyl-enzyme intermediate, all peptide substrates could in principle be used as acyl-components in such transacylation reactions. Thus, CPD-Y might be able through its peptidase activity to catalyze the exchange of the C-terminal amino acid residue in peptides for various other groups. Some of the reactions that CPD-Y potentially could catalyze are listed in Scheme 1:

\section{Scheme 1}

Possible CPD-Y catalyzed exchanges of C-terminal amino acid residues in peptides. $\mathrm{X}, \mathrm{Y}$ and $\mathrm{Z}$ represents amino acid residues.

I. Conversion of peptides to peptide esters
a. $-\mathrm{X}-\mathrm{Y}-\mathrm{OH}+\mathrm{MeOH} \rightarrow-\mathrm{X}-\mathrm{OMe}+\mathrm{H}-\mathrm{Y}-\mathrm{OH}$
b. $-\mathrm{X}-\mathrm{Y}-\mathrm{OH}+\mathrm{H}-\mathrm{Z}-\mathrm{OMe} \rightarrow-\mathrm{X}-\mathrm{Z}-\mathrm{OMe}+\mathrm{H}-\mathrm{Y}-\mathrm{OH}$

II. Conversion of peptides to peptide amides
a. $-\mathrm{X}-\mathrm{Y}-\mathrm{OH}+\mathrm{NH}_{3}$
$\rightarrow-\mathrm{X}-\mathrm{NH}_{2}+\mathrm{H}-\mathrm{Y}-\mathrm{OH}$
b. $\cdot \mathrm{X}-\mathrm{Y}-\mathrm{OH}+\mathrm{H}-\mathrm{Z}-\mathrm{NH}_{2} \rightarrow \cdot \mathrm{X}-\mathrm{Z}-\mathrm{NH}_{2}+\mathrm{H}-\mathrm{Y}-\mathrm{OH}$

III. Conversion of peptides to other peptides

a. $-\mathrm{X} \cdot \mathrm{Y} \cdot \mathrm{OH}+\mathrm{H}-\mathrm{Z}-\mathrm{OH} \rightarrow-\mathrm{X}-\mathrm{Z} \cdot \mathrm{OH}+\mathrm{H} \cdot \mathrm{Y}-\mathrm{OH}$

An earlier report from this laboratory (3) has already indicated that CPD-Y can catalyze reaction IIb. In the present communication it is demonstrated that all the reactions listed in Scheme 1 are catalyzed by CPD-Y.

\section{MATERIALS AND METHODS}

\subsection{Materials}

Carboxypeptidase Y from baker's yeast, a commercial preparation of the Carlsberg Breweries, was isolated by a modification of the affinity chromatographic procedure of JOHANSEN et al. (9) and obtained as a lyophilized powder (10\% enzyme in sodium citrate). Before use the enzyme was desalted on a Sephadex G-25 fine column $(1.5 \times 25 \mathrm{~cm})$ equilibrated and eluted with water. The concentration of the enzyme was determined spectrophotometrically using $\mathrm{E}_{280 \mathrm{~nm}}^{1 \%}=14.8$. The enzyme preparation used was free of protease A activity as checked by the assay of LEE and RIORDAN (12).

Benzoyl-L-phenylalanyl-glycine was synthesized from benzoylchloride and L-phenylalanineglycine according to a method described by
Auld and VAlLeE (2). N-CBZ-L-alanyl-L-alanine, N-CBZ-L-alanyl-glycine, N-CBZ-L-alanyl-Lvaline, N-CBZ-L-alanyl-L-methionine, N-CBZ-Lalanyl-L-phenylalanine, N-CBZ-L-alanyl-L-serine, N-CBZ-L-alanyl-L-lysine, N-CBZ-L-alanyl-L-histidine, N-CBZ-L-alanyl-L-arginine, NCBZ-L-alanyl-L-asparagine, N-CBZ-L-valyl-L-valine, N-CBZ-L-leucyl-L-valine, N-CBZ-L-isoleucyl-L-valine, N-CBZ-L-phenylalanyl-L-valine, and N-CBZ-L-alanyl-L-aspartic acid were all obtained from Bachem, Switzerland. Glycinemethylester-hydrochloride and glycineamide hydrochloride were purchased from Fluka, Switzerland. Glycine was a product of Sigma, USA.

\subsection{Methods}

All enzymatic reactions were performed in a $\mathrm{pH}$ stat. Due to the low solubility of some substrates, several reactions had to be carried out with the substrate only partly dissolved. The initial concentrations are therefore not known in these cases. At various times aliquots were diluted into acetonitrile to quench the reaction. The composition of the reaction mixtures was 
determined by HPLC as previously described (20). Two eluant systems were used: 1) A-buffer: $10 \mathrm{~mm}$-sodium acetate, $\mathrm{pH} 4.0$, B-buffer: $80 \%$ $\mathrm{CH}_{3} \mathrm{CN}+20 \%$ A. 2) A-buffer: $50 \mathrm{~mm}$-TEAF, pH 3.5, B-buffer: $80 \% \mathrm{CH}_{3} \mathrm{OH}+20 \%$ A. All separations were carried out at room temperature and monitored at $254 \mathrm{~nm}$. The two buffer systems supplemented each other, since separations not possible in one system were always possible using the other system. The products were identified by parallel runs of the relevant standards or by amino acid analysis. In all cases the compounds of interest had a dominant chromophore (Bz- or Z-) such that the relative concentrations could be assessed from the integrated peak areas.

\section{RESULTS}

To study the reactions listed in Scheme 1 it is necessary to work in a $\mathrm{pH}$ range where both the peptides are substrates of CPD-Y (pH 3-9.5) and the nucleophiles also can perform their attack on the acyl-enzyme intermediate. Hence, the effect of $\mathrm{pH}$ was studied for each of the listed reactions. However, to monitor the reactions it is essential that the products will accumulate in the $\mathrm{pH}$ range of interest. While the aminolysis experiments (Reactions Ib, IIa, IIb and III) could be designed such that this requirement was fulfilled, the yield of alcoholysis (Reaction Ia) could only by studied in a very narrow $\mathrm{pH}$ range, since the reaction products, i.e. peptide esters, are degraded by CPD-Y over part of the $\mathrm{pH}$ range where peptides function as substrates of CPD-Y.

\subsection{Modification of peptides by alcoholysis}

The conversion of peptides to peptide esters by alcoholysis (Reaction Ia) was studied using BzPhe-Gly-OH as substrate and methanol as nucleophile. A partitioning between $\mathrm{Bz}-\mathrm{Phe}-\mathrm{OH}$ and $\mathrm{Bz}-\mathrm{Phe}-\mathrm{OMe}$ thus takes place. In the presence of $25 \%$ methanol, $33 \%$ Bz-Phe-OMe is formed at $\mathrm{pH} 3.5$ (Figure 1, upper panel), and as shown in the lower panel the synthesized peptide ester accumulates in the reaction mixture. At $\mathrm{pH} \mathrm{4,} \mathrm{the} \mathrm{results} \mathrm{are} \mathrm{the} \mathrm{same} \mathrm{except}$

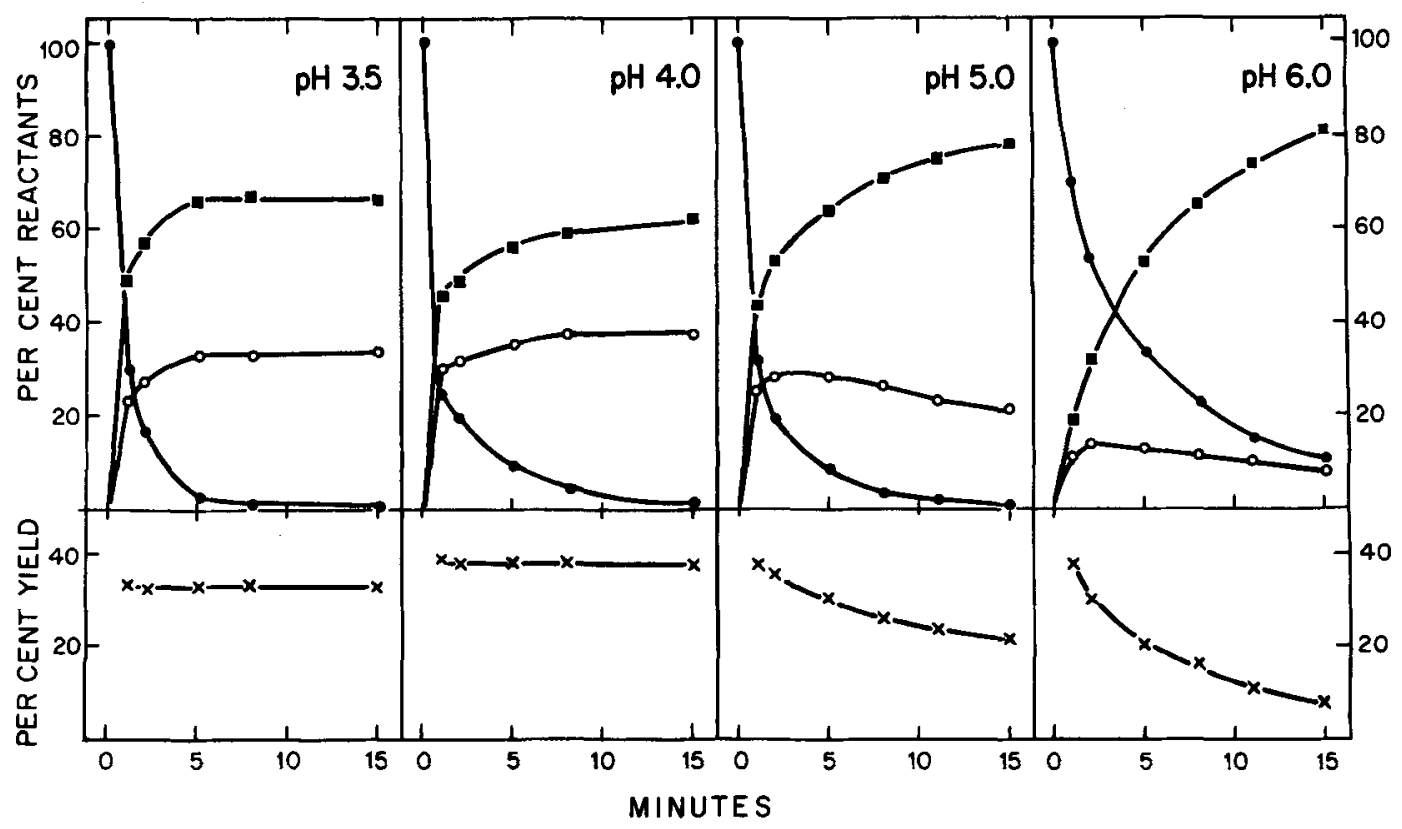

Figure 1. pH dependence of CPD-Y catalyzed methanolysis of Bz-Phe-Gly-OH. Conditions: $8 \mathrm{~mm}-\mathrm{Bz}-\mathrm{Phe}-\mathrm{Gly}$ $\mathrm{OH}, 25 \% \mathrm{CH}_{3} \mathrm{OH}, 0.1 \mathrm{M}-\mathrm{KCl}, 2 \mathrm{~mm}-\mathrm{EDTA}$. Enzyme concentrations varied: $\mathrm{pH}$ 3.5: $6.8 \mu \mathrm{M}, \mathrm{pH}$ 4.0: $2.4 \mu \mathrm{M}$, $\mathrm{pH}$ 5.0: $1.4 \mu \mathrm{M}, \mathrm{pH}$ 6.0: $0.7 \mu \mathrm{M}$. Upper panel indicates percentage of reactants: $-0-0-\mathrm{Bz}-\mathrm{Phe}-\mathrm{Gly}-\mathrm{OH}$, - $-\mathrm{Bz}-\mathrm{Phe}-\mathrm{OH},-\mathrm{O}-\mathrm{O}-\mathrm{O}-\mathrm{Bz}-\mathrm{Phe}-\mathrm{OMe}$. Lower panel indicates coupling yield, i.e., Bz-Phe-OMe/(BzPhe-OMe + Bz-Phe-OH). 
Table I

Maximal alcoholysis yields for the CPD-Y catalyzed conversion of Bz-Phe-Gly-OH to estersa)

\begin{tabular}{lcc}
\hline $\mathrm{X}-\mathrm{OH}$ & $\begin{array}{c}\text { \% alcohol } \\
\text { (v/v) }\end{array}$ & $\begin{array}{c}\text { \% yield } \\
\text { (Bz-Phe-OX) }\end{array}$ \\
\hline $\mathrm{CH}_{3} \mathrm{OH}$ & 47 & 58 \\
$\mathrm{CH}_{3} \mathrm{CH}_{2} \mathrm{OH}$ & 33 & 35 \\
$\mathrm{HOCH}_{2} \mathrm{CH}_{2} \mathrm{OH}$ & 75 & 45 \\
$\mathrm{CH}_{3} \mathrm{OCH}_{2} \mathrm{CH}_{2} \mathrm{OH}$ & 47 & 25 \\
\hline
\end{tabular}

a) Conditions: $10 \mathrm{~mm}-\mathrm{Bz}-\mathrm{Phe}-\mathrm{Gly}-\mathrm{OH}, 0.1 \mathrm{~m}-\mathrm{KCl}, 2$ mm-EDTA, $\mathrm{pH}_{\text {app }} 4.0$, CPD-Y $=6 \mu \mathrm{m}$, aliquots taken at 2-15 min. where $65-85 \%$ Bz-Phe-Gly-OH was converted.

that $38 \% \mathrm{Bz}-\mathrm{Phe}-\mathrm{OMe}$ is formed, but at higher $\mathrm{pH}$ the observed yield of the conversion of $\mathrm{Bz}$ Phe-Gly-OH to Bz-Phe-OMe decreases as the initial substrate is used up, indicating that as the reaction progresses, the hydrolysis of Bz-Phe$\mathrm{OMe}$ becomes increasingly dominant. This suggests that Reaction Ia should be performed at pH 4 or below.

The reactions shown in Figure 1 were performed at $25 \%$ methanol $(\mathrm{v} / \mathrm{v})$, since at this concentration the enzyme was active at all $\mathrm{pH}$ values studied for at least 15 minutes. Increasing the concentration of methanol above $25 \%$, caused inactivation of the enzyme, but simultaneously the coupling yield increased. Conditions where $75 \%$ of the initial substrate is consumed before the enzyme is completely inactivated have been applied to estimate the maximum yield of ester synthesis. In Table I such yields for four different alcohols are compared. Using methanol, a coupling yield of $58 \%$ is obtained, i.e. the reaction mixture consisted of $25 \%$ Bz-Phe-Gly$\mathrm{OH}, 44 \% \mathrm{Bz}-\mathrm{Phe}-\mathrm{OMe}$ and $31 \% \mathrm{Bz}-\mathrm{Phe}-\mathrm{OH}$. Using ethanol, ethylene glycol or methyl cellosolve as nucleophiles, resulted in lower coupling yields, suggesting that conversion of peptides to peptide esters by alcoholysis can best be performed using methanol as nucleophile.

\subsection{Modification of peptides by anrinolysis}

The aminolysis reactions listed in Scheme 1 (Reaction Ib, IIa, IIb and III) were all performed using Z-Ala-Ala-OH as substrate and glycine and glycine derivatives as nucleophiles, since most compounds with a C-terminal glycine residue are very slowly hydrolyzed by CPD-Y, thus rendering the coupling products stable under the required reaction conditions. This insured that the problems encountered with the conversion of peptides to peptide esters were not observed for the aminolysis reactions. However, one of the products, Z-Ala-Gly-OMe, was not completely resistant towards further conversion since an oligomerization took place at $\mathrm{pH}>8.5$. The explanation of this lies in the low peptidase activity at high $\mathrm{pH}$, while the esterase activity is high (7). At $\mathrm{pH}<8.5$, the amount of oligomer was less than $10 \%$ of the reaction products. In other reactions with amine nucleophiles, no similar problems were observed.

The $\mathrm{pH}$ dependence of the product yields using $\mathrm{H}-\mathrm{Gly}-\mathrm{OH}, \mathrm{H}-\mathrm{Gly}-\mathrm{OMe}, \mathrm{H}-\mathrm{Gly}-\mathrm{NH}_{2}$ and $\mathrm{NH}_{3}$ as nucleophiles and $\mathrm{Z}$-Ala-Ala-OH as substrate is shown in Figure 2. It is apparent that two of the glycine derivatives, H-Gly-OMe and H-Gly$\mathrm{NH}_{2}$ behave in a similar manner. Increasing the $\mathrm{pH}$ from 5 , results in sharp increase in the coupling yields, reaching $100 \%$ for the forma-

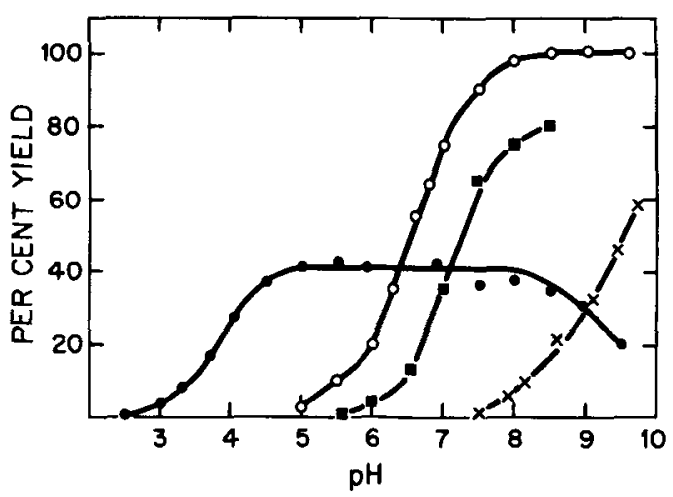

Figure 2. $\mathrm{pH}$ dependence of aminolysis of $20 \mathrm{~mm}-\mathrm{Z}$ Ala-Ala-OH using various amine nucleophiles. Conditions: -O-O-O- 1 M-H-Gly-OH, -O-O-Ol $\mathrm{M}-\mathrm{H}-\mathrm{Gly}-\mathrm{NH}_{2},-\square-\square-\square-1$ M-H-Gly-OMe, $-x-x-x-5 \mathrm{~m}-\mathrm{NH}_{3}$. Enzyme concentration and reaction time were chosen such that more than $80 \%$ $\mathrm{Z}$-Ala-Ala-OH was consumed in the reaction except at $\mathrm{pH} 9.5$ where only $50 \%$ was consumed. For the glycine derivatives the enzyme concentration was: $\mathrm{pH}$ 5-7: $1.5 \mu \mathrm{M}, \mathrm{pH} 7.5-8: 3 \mu \mathrm{M}, \mathrm{pH}$ 8.5: $6 \mu \mathrm{M}, \mathrm{pH} 9$ 9.7: $12 \mu \mathrm{M}$. The reaction time was $1-6 \mathrm{~min}$. except at pH 9.5 where it was $20 \mathrm{~min}$. When $\mathrm{NH}_{3}$ was used as nucleophile, the enzyme concentration was kept constant at $6 \mu \mathrm{M}$, while reaction time varied: $\mathrm{pH} 9.4$ 30 min., pH 9.1: 25 min., pH 8.6; 12 min., pH 8.15: $6 \mathrm{~min} ., \mathrm{pH} 7.9: 2 \mathrm{~min}$, $\mathrm{pH}$ 7.5: $2 \mathrm{~min}$. 
tion of Z-Ala-Gly-NH2 and $80 \%$ for the formation of Z-Ala-Gly-OMe. The aminolysis is apparently dependent on the deprotonation of an ionizable group with a $\mathrm{pK}_{\mathrm{a}}$ of 6.6 for H-Gly$\mathrm{NH}_{2}$ and 7.1 for H-Gly-OMe. In contrast, the formation of Z-Ala-Gly-OH from Z-Ala-Ala$\mathrm{OH}$ and $\mathrm{H}-\mathrm{Gly}-\mathrm{OH}$ (Scheme 1, Reaction III) is observed even at $\mathrm{pH} 3$. Increasing the $\mathrm{pH}$ above this value, results in a sharp increase in the

\section{Table II}

The influence of the amino acid leaving group on coupling yields in CPD-Y catalyzed transpeptidations.

\begin{tabular}{|c|c|c|}
\hline Substrate & $\begin{array}{c}\mu \mathrm{M} \\
\mathrm{CPD} \cdot \mathrm{Y}\end{array}$ & $\begin{array}{c}\text { Yield (\%) } \\
\text { of Z-Ala-Gly- } \mathrm{NH}_{2}\end{array}$ \\
\hline
\end{tabular}

\begin{tabular}{lcr}
\hline Z-Ala-Gly-OH & 11 & 85 \\
Z-Ala-Ala-OH & 3.5 & 100 \\
Z-Ala-Ser-OH & 5 & 85 \\
Z-Ala-Arg-OH & 5 & 90 \\
Z-Ala-Pro-OH & 11 & 80 \\
Z-Ala-Lys-OH & 5 & 95 \\
Z-Ala-Asn-OH & 5 & 95 \\
Z-Ala-His-OH & 5 & 25 \\
Z-Ala-Val-OH & 3.5 & 10 \\
Z-Ala-Met-OH & 3.5 & 10 \\
Z-Ala-Phe-OH & 3.5 & 10 \\
Z-Ala-Asp-OH & 22 & - \\
\hline
\end{tabular}

Conditions: $20 \mathrm{~mm}$-substrate, $1.0 \mathrm{~m}-\mathrm{H}-\mathrm{Gly}-\mathrm{NH}_{2} \mathrm{pH}$ 8.0. Reaction terminated at $2-30 \mathrm{~min}$. No turnover could be detected with Z-Ala-Asp-OH. For other substrates approximately $70 \%$ of the initial substrate was consumed in the reaction.

Table III coupling yield, which becomes constant at $\mathrm{pH} 5-$ $8(41 \%)$ and decreases at $\mathrm{pH}>8$. The aminolysis is apparently dependent on an ionizable group with $\mathrm{pK}_{a}$ of 3.8 and possibly also on a group with a $\mathrm{pK}_{\mathrm{a}}$ of 9-9.5. Apparently the amino acid derivatives with a blocked carboxylic acid group exhibit a behaviour different from the corresponding free amino acid.

The incorporation of ammonia to substitute for the C-terminal amino acid residue in Z-AlaAla-OH to form Z-Ala- $\mathrm{NH}_{2}$ (Reaction Ila) takes place only at basic $\mathrm{pH}$. The aminolysis is dependent on the deprotonation of an ionizable group with a $\mathrm{pK}_{\mathrm{a}}$ of approximately 9.4 , but due to the absence of peptidase activity at $\mathrm{pH}>9.7$, the exact value cannot be established.

The results in Figure 2 thus suggest that the exchange of a C-terminal amino acid residue in a peptide for an amino acid ester (Reaction Ib) or an amino acid amide (Reaction Ilb) occur at $\mathrm{pH}$ $>8$, while the exchange of the C-terminal residue (Reaction III) is possible at $\mathrm{pH} 5-8$, i.e. under conditions where CPD-Y exhibits high peptidase activity. In contrast, the conversion of a peptide to a peptide amide using ammonia as nucleophile (Reaction IIa), should preferable be performed at $\mathrm{pH}>9.5$, i.e., under conditions where CPD-Y exhibits very little peptidase activity.

\subsection{The influence of the substrate structure on the yield of transacylation}

To investigate the influence of the C-terminal amino acid residue of peptide substrates on the

The influence of the amino acid leaving group in CPD-Y catalyzed transacylations.

\begin{tabular}{lccccc}
\hline & \multicolumn{5}{c}{ \% Coupling yield with the following nucleophiles } \\
\cline { 2 - 6 } Substrate & H-Gly-OH $^{\text {a) }}$ & H-Gly-NH2 & H-Gly-OMe & $\mathrm{CH}_{3} \mathrm{OH}^{\text {b) }}$ & $\mathrm{NH}_{3}^{\text {c) }}$ \\
\hline Z-Ala-Ala-OH & 40 & 100 & 75 & 40 & 75 \\
Z-Ala-Val-OH & 5 & 10 & 15 & 20 & 15 \\
Z-Ala-Met-OH & 5 & 10 & 10 & 15 & 20 \\
Z-Ala-Phe-OH & 0 & 0 & - & 15 & 15 \\
\hline
\end{tabular}

Conditions: All reactions performed with $20 \mathrm{~mm}$-substrate, $0.1 \mathrm{M}-\mathrm{KCl}, 2 \mathrm{~mm}$-EDTA, room temperature. a) 1.0 M-nucleophile, $\mathrm{pH} 8.0, \mathrm{CPD}-\mathrm{Y}=3.5 \mu \mathrm{M}$, aliquots taken at $1-15 \mathrm{~min}$. b) $40 \% \mathrm{CH}_{3} \mathrm{OH}(\mathrm{v} / \mathrm{v}), \mathrm{pH}_{\mathrm{app}} 4.0, \mathrm{CPD}-\mathrm{Y}$ $=6 \mu \mathrm{M}$, aliquots taken at $5 \mathrm{~min}$. c) $8.8 \mathrm{M}-\mathrm{NH}_{3}, \mathrm{pH} 9.5, \mathrm{CPD}-\mathrm{Y}=10 \mu \mathrm{M}$, aliquots taken at $30-100 \mathrm{~min}$. The coupling yield refers to the percentage of the coupling product (Z-Ala-Gly-OH, Z-Ala-Gly-NH $2, \mathrm{Z}-\mathrm{Ala}-\mathrm{Gly}$ $\mathrm{OMe}, \mathrm{Z}$-Ala-OMe, $\mathrm{Z}$-Ala- $\mathrm{NH}_{2}$ ) relative to all products formed when approximately $80 \%$ of the substrates were converted. 
Table IV

The influence of the penultimate amino acid residue on the coupling yields in CPD-Y catalyzed transpeptidations.

\begin{tabular}{lcc}
\hline Substrate & $\begin{array}{c}\mu \mathrm{M} \\
\text { CPD-Y }\end{array}$ & $\begin{array}{c}\text { Yield (\%) } \\
\text { of Z-X-Gly-NH }\end{array}$ \\
\hline Z-Ala-Val-OH & 3.5 & 10 \\
Z-Val-Val-OH & 5 & 40 \\
Z-Leu-Val-OH & 2.5 & 35 \\
Z-Ile-Val-OH & 2.5 & 45 \\
Z-Phe-Val-OH & 2.5 & 5 \\
\hline
\end{tabular}

Conditions: See Table II

yield of the transacylation reactions listed in Scheme 1, a series of N-blocked dipeptides with different $\mathrm{C}$-terminal amino acid residue were investigated. Using $\mathrm{H}-\mathrm{Gly}-\mathrm{NH}_{2}$ as nucleophile, it is apparent that the coupling yield is strongly dependent on the nature of the C-terminal amino acid residue (Table II). The yields vary from 10 to $100 \%$, with the lowest yields obtained with substrates where a hydrophobic amino acid serves as leaving group. In other transacylation experiments, using $\mathrm{H}-\mathrm{Gly}-\mathrm{OMe}$, H-Gly-OH, $\mathrm{NH}_{3}$ and methanol as nucleophiles, the same pattern is observed: High yield when the leaving group is a hydrophilic amino acid, e.g. in Z-AlaAla-OH and low yield when the leaving group is a hydrophobic amino acid, e.g. in Z-Ala-Val-OH (Table III).

The influence of the penultimate amino acid residue of peptide substrates was investigated using a series of $\mathrm{N}$-blocked dipeptides with different penultimate amino acid residue and valine as C-terminal amino acid residue. Using $\mathrm{H}-\mathrm{Gly}-\mathrm{NH}_{2}$ as nucleophile, it is apparent that the coupling yield is dependent on the penultimate amino acid residue albeit with no obvious trend (Table IV).

\section{DISCUSSION}

It is well-known that a variety of nucleophiles can compete with water in the deacylation step of serine proteases (5). If the nucleophile is an amino acid or an amino acid derivative, a peptide bond is formed. Among the many enzymes described to be capable of catalyzing such reactions (reviewed by J. FrUTON (6)) CPD-Y offers some unique features. The $\mathrm{pH}$ optima for the CPD-Y catalyzed hydrolysis of peptides and esters are sufficiently different (7) that the enzyme at basic $\mathrm{pH}$ has high esterase activity and almost no peptidase activity, while at acidic $\mathrm{pH}$ the enzyme has peptidase activity and almost no esterase activity. This enables the enzyme at basic $\mathrm{pH}$ to catalyze the reaction: $\mathrm{Z}$-Ala-OMe + $\mathrm{H}-\mathrm{Ala}-\mathrm{OH} \rightarrow \mathrm{Z}$-Ala-Ala-OH $+\mathrm{MeOH}(18)$, a property which has great potential in step-wise peptide synthesis (21). At acidic $\mathrm{pH}$ the enzyme catalyzed the reverse reaction, i.e. the formation of esters from peptides and alcohols (Reaction Ia) as demonstrated in the present publication. Importantly, the reaction products are stable in both cases, enabling their isolation from the reaction mixture. The enzyme catalyzed formation of peptide esters from peptides is of interest for protein semisynthesis, since it represents a method for removing a C-terminal amino acid residue from a peptide to form a peptide ester, which then can be utilized as acyl-component in subsequent protease catalyzed reactions using amino acid derivatives or peptides as amine components. The highest alcoholysis yield, $58 \%$, was obtained with methanol (Table I), but even higher yields might be obtained if the enzyme could be stabilized towards denaturation in methanol, allowing higher concentrations to be used. Performing the reaction at low temperature or with immobilized enzyme are possibilities to be explored.

It was not possible to study the $\mathrm{pH}$ dependence of the coupling yield for the conversion of peptides to peptide esters above pH 4.0. Similar problems were not encountered to any significant degree when various amines were used as nucleophiles. The aminolysis with two nucleophiles with blocked carboxyl groups, $\mathrm{H}-\mathrm{Gly}-\mathrm{NH}_{2}$ and H-Gly-OMe, were dependent on the deprotonation of an ionizable group with a $\mathrm{pK}_{\mathrm{a}}$ of 6.6 and 7.1 , respectively, whereas the aminolysis with $\mathrm{H}-\mathrm{Gly}-\mathrm{OH}$ was dependent on the deprotonation of a group with a $\mathrm{pK}_{\mathrm{a}}$ of 3.8 . The $\mathrm{pH}$ profiles of these reactions thus indicate that the aminolysis with the glycine nucleophiles is not a reflection of the $\mathrm{pK}_{\mathrm{a}}$ values of their amino groups (H-Gly-OH: $\mathrm{pK}_{\mathrm{a}} \sim 9.6, \mathrm{H}-\mathrm{Gly}-\mathrm{NH}_{2}$ : $\mathrm{pK}_{\mathrm{a}} \sim$ 7.9, H-Gly-OMe: $\mathrm{pK}_{\mathrm{a}} \sim$ 7.8). Hence, ionizable groups on the enzyme are responsible for the observed $\mathrm{pH}$ profiles, which most likely reflect the binding of the nucleophiles to the 
active site of the enzyme prior to minolysis. In this context it is interesting that the binding of $\mathrm{N}$ blocked dipeptides increase with the protonation of a residue with $\mathrm{pK}_{\mathrm{a}}$ of approximately 6.5 (7). This residue possibly provides a positive charge, like the one described to be typical for the binding site in metallo-carboxypeptidases for the C-terminal carboxylate group of peptide substrates (16). It is conceivable that the protonation of the same residue prevents the binding of H-Gly$\mathrm{NH}_{2}$ and $\mathrm{H}-\mathrm{Gly}-\mathrm{OMe}$, whereas the negatively charged carboxylate group in $\mathrm{H}-\mathrm{Gly}-\mathrm{OH}$ facilitates binding of this nucleophile, and hence might explain the different $\mathrm{pH}$ profiles observed for these nucleophiles.

The present study indicates that the ultimate as well as the penultimate amino acid residue of the substrate exerts a pronounced influence on the ratio of aminolysis to hydrolysis. In an earlier publication (3), it was suggested that the size of the leaving group was an important factor determining the yield in transpeptidation reactions when amino acid amides were used as nucleophiles. However, it is now indicated that it is the hydrophobicity of the amino acid leaving the active site which affects the ratio of aminolysis to hydrolysis rather than its size (Table II). These differences may be explained by assuming that aminolysis in contrast to hydrolysis, depends on the rate of dissociation of the leaving group from the active site and further that the leaving group and the nucleophile compete for the same binding site, i.e. the $S_{1}$ binding site (Berger-Schechter nomenclature (17)). It is important to note that for all the types of nucleophiles used in this study (H-Gly-OH, HGly- $\mathrm{NH}_{2}, \mathrm{H}-\mathrm{Gly}-\mathrm{OMe}, \mathrm{NH}_{3}$ and $\left.\mathrm{CH}_{3} \mathrm{OH}\right)$ a similar dependence of the leaving group is observed (Table III). This indicates that they all occupy the same binding site as the leaving group before their nucleophilic attack on the enzyme. This behaviour also suggests that the water molecule involved in hydrolysis binds to the active site at a different position.

The influence of the penultimate residue on the yield of transpeptidation cannot be explained by its hydrophobicity or size (Table IV). However, it is conceivable that the degree on aminolysis depends on the life-time of the acylenzyme intermediate. The ratio of aminolysis to hydrolysis may thus be high even when peptides with hydrophobic C-terminal amino acid residues are used as substrates, provided that the life-time of the acyl-enzyme intermediate is sufficiently long for the leaving group to dissociate from the active site and the nucleophile to occupy its proper position for nucleophilic attack.

While the present experiments can only outline some possibilities for the mechanism of CPD-Y catalyzed peptide synthesis, certain preparative aspects of its use are apparent. For the evaluation of the feasibility of a given reaction, knowledge about the relative rates of acylation of the initial substrate and the coupling product is essential. We have demonstrated that all the reactions described in Scheme 1 are catalyzed by CPD-Y, and that the products can be accumulated, but it should be emphasized that the glycine nucleophiles were chosen because the resultant products were poor substrates of CPD-Y. In less favorable cases, the use of ammonia, amino acid esters and free amino acids as nucleophiles might not be possible. It should however generally be possible to convert peptides to peptide esters and peptide amides using alcohols and amino acid amides as nucleophiles, respectively, since in these cases the rates of acylation is far higher for the peptide substrate than for the product under the conditions of coupling.

The present results suggest that CPD-Y could be used in C-terminal modifications of longer peptides and proteins. The use of this enzyme represents an attractive alternative to the kind of reactions previously performed on insulin, where the exchange is dependent on the specific removal of the $\mathrm{C}$-terminal amino acid residue with carboxypeptidase A in a separate step (13, 14). Such manipulations are only possible using suitably composed peptides whereas the present method using CPD-Y is more generally applicable. The incorporation of labelled amino acids as well as reporter groups into the C-terminal portion of proteins represents other possibilities for the use of CPD-Y in protein semisynthesis.

Transacylation reactions have been described for numerous proteolytic enzymes (6). However, specific replacements of $\mathrm{C}$-terminal amino acids and the conversion of a peptide bond to an ester bond by alcoholysis have not yet been described for any other enzyme. Esterification of $\mathrm{N}$ blocked amino acids using endopeptidases as 
catalysts $(8,10,11,15)$ have been performed, but the reactions were carried out under such special conditions that they most likely cannot be used in protein semisynthesis.

\section{ACKNOWLEDGEMENTS}

We are grateful to professor MARTIN OTTESEN for his interest and help with our work, and professor JOSEPH FRUTON for a preprint of his forthcoming review on enzymic synthesis of peptide bonds (6). The technical assistance of Mss. Bodil Corneliussen, Pia Poulsen and MeRETE SONNE is deeply appreciated. Fred W IDMER gratefully acknowledges the Swiss National Science Foundation for a Fellowship.

\section{REFERENCES}

1. Auld, D. S.: Direct observation of transient ES complexes: The implications to enzyme mechanisms. Bioorganic Chemistry (Van Tamelin, E. E., Ed.) Vol. 1, p. 1 (1977), Academic Press, New York.

2. Auld, D. S. \& B. L. Vallee: Kinetics of carboxypeptidase A. Il. Inhibitors of the hydrolysis of oligopeptides. Biochemistry 9, 602-609 (1970)

3. Breddam, K., F. Widmer \& J. T. Johansen: Carboxypeptidase $\mathrm{Y}$ catalyzed transpeptidations and enzymatic peptide synthesis. Carlsberg Res. Commun. 45, 237-247 (1980)

4. Breddam, K, F. Widmer \& J. T, Johansen: Influence of the substrate structure on carboxypeptidase $Y$ catalyzed peptide bond formation. Carlsberg Res. Commun. 45, 361-367 (1980)

5. Fastrez, J. \& A. R. Ferscht: The demonstration of the acyl-enzyme mechanism for the hydrolysis of peptides and anilides by chymotrypsin. Biochemistry 12, 2025-2034 (1973)

6. Fruton, J. S.: Enzymic synthesis of peptide bonds. In Adv. Enzymol., A. Meister ed., John Wiley, New York (in press) (1981)

7. Hayashi, R., Y. Bai \& T. Hata: Kinetic studies of carboxypeptidase Y. I. Kinetic parameters for hydrolysis of synthetic substrates. J. Biochem. (Tokyo) 77, 69-79 (1975)

8. Ingalis, R. G., R. G. Squires \& L. G. Butler: Reversal of enzymatic hydrolysis: Rate and extent of ester synthesis as catalyzed by chymotrypsin and subtilisin Carlsberg at low water concentration. Biotech. Bioeng. 18, 1627-1637 (1975)

9. Johansen, J. T., K. Breddam \& M. Ottesen:
Isolation of carboxypeptidase $\mathrm{Y}$ by affinity chromatography. Carlsberg Res. Commun. 41. 1-14 (1976)

10. Kapane, A. \& V. Kasche: Kinetically controlled equilibria. The pertubation of hydrolysis equilibria in reactions catalyzed by $\alpha$-chymotrypsin immobilized on charges supports. Biochem. Biophys. Res. Commun. 80, 955-962 (1978)

11. Kubanov, A. M., G. P. Samokhin, K. MartiNEK \& I. V. BEREZIN: A new approach to preparative enzymatic synthesis. Biotechnol. Bioeng. 19, 1351-1361 (1977)

12. LeE, H.-M. \& J. F. Riordan: Does carboxypeptidase $Y$ have intrinsic endopeptidase activity. Biochem. Biophys. Res. Commun 85, 11351142 (1978)

13. Morihara, K., T. Oka \& H. Tsuzuki: Semisynthesis of human insulin by trypsin-catalyzed replacement of Ala-B 30 by Thr in porcine insulin. Nature 280, 412-413 (1979)

14. Morihara, K., T. OKa, H. Tsuzuki, Y. Tochino \& T. Kanaya: Achromobacter protease I catalyzed conversion of porcine insulin into human insulin. Biochem. Biophys. Res. Commun. 92, 396-402 (1980)

15. Nakamoto, Y., I. Karube, I. Kobayashi, M. Nishida \& S. SuzukJ: Amino acid esterification by $\alpha$-chymotrypsin immobilized in spiropyran membrane. Arch. Biochem. Biophys. 193, 117121 (1979)

16. Riordan, J. F.: Arginyl residues and anion binding sites in proteins. Molec. Cell. Biochem. 26, 71-92 (1979)

17. Schechter, I. \& A. Berger: On the size of the active site in proteases. I. Papain. Biochem. Biophys. Res. Commun. 27, 157-162 (1967)

18. Widmer, F. \& J. Johansen: Enzymatic peptide synthesis. Carboxypeptidase Y catalyzed formation of peptide bonds. Carlsberg Res. Commun. 44, 37-46 (1979)

19. Widmer, F., K. Breddam \& J. T. Johansen: Carboxypeptidase $Y$ catalyzed peptide synthesis using amino acid alkyl esters as amine components. Carlsberg Res. Commun. 45, 453-463 (1980)

20. Widmer, F., K. Breddam \& J. T. Johansen: Influence of the structure of amine components on carboxypeptidase $\mathrm{Y}$ catalyzed amide bond formation. Carlsberg Res. Commun. 46, 97-106 (1981)

21. Widmer, F., K. Breddam \& J. T. Johansen: Carboxypeptidase $\mathrm{Y}$ as a catalyst for peptide synthesis in aqueous phase with minimal protection. In: Proc. 16th European Peptide Symposium. K. Brunfeldt ed., Scriptor, Copenhagen pp. 46-55 (1981) 